\section{How Well Do Critical Nitrogen Concentrations Work for Cabbage, Carrot, and Onion Crops?}

\author{
Sean M. Westerveld ${ }^{1}$, Alan W. McKeown ${ }^{2}$, Cynthia D. Scott-Dupree ${ }^{3}$, \\ and Mary Ruth McDonald ${ }^{4}$ \\ University of Guelph, Guelph, Ontario, NIG 2W1 Canada
}

Additional index words. vegetables, nutrient management, plant analysis

\begin{abstract}
With the introduction of nutrient management legislation in Ontario, there is a need to improve the efficiency of nitrogen $(\mathrm{N})$ utilization. One possibility is to use critical nutrient concentrations in plant tissue as an indicator of the $\mathbf{N}$ nutritional status of the crop. Plant tissue analysis was used to determine the total $\mathrm{N}$ and nitrate- $\mathrm{N}\left(\mathrm{NO}_{3}-\mathrm{N}\right)$ concentrations of cabbage (Brassica oleracea var. capitata $\mathbf{L}$.), carrots (Daucus carota L.), and onions (Allium cepa L.) grown in Ontario. The tissue samples were collected from plants as part of $\mathrm{N}$ fertilization studies from 1999 to 2001 on the organic soils in the Holland/Bradford Marsh area and the mineral soils near Simcoe, Ontario. Yield was assessed at harvest as an indicator of the $\mathrm{N}$ requirement of the crop. Testing the usefulness of critical $\mathrm{NO}_{3}-\mathrm{N}$ concentrations to indicate the $\mathrm{N}$ requirement of the crop was problematic because: 1) few published references were available to indicate a critical level of $\mathrm{NO}_{3}-\mathrm{N}$ in these crops; 2) tissue $\mathrm{NO}_{3}-\mathrm{N}$ concentrations were highly variable; and 3) field data rarely matched published references. Tissue total $\mathrm{N}$ concentrations from the trials corresponded to published critical $\mathrm{N}$ concentrations in some cases, however, the use of published critical $\mathbf{N}$ concentrations would have resulted in either over or under-application of fertilizer to the crops. Cultivar, soil type, and climate were shown to affect tissue $\mathbf{N}$ concentrations. Based on these results it was concluded that local research and field verification is required before tissue $\mathbf{N}$ critical nutrient concentrations become useful for determining fertilizer needs of cabbage, carrots, and onions grown in Ontario.
\end{abstract}

Vegetable growers in Ontario may be required by law to restrict nitrogen $(\mathrm{N})$ application and improve $\mathrm{N}$ efficiency. Consequently, the importance of techniques such as tissue and soil $\mathrm{N}$ analysis is expected to increase. Although research elsewhere over the past decade has focussed on numerous alternative techniques such as factoring in growth rates (Scaife, 1988) and the Diagnosis and Recommendation Integrated System (DRIS) (Sumner, 1990), traditional plant tissue $\mathrm{N}$ (including nitrate- $\mathrm{N}\left(\mathrm{NO}_{3}-\mathrm{N}\right)$ and total $\left.\mathrm{N}\right)$ analysis remains the fertilizer recommendation method of choice in Ontario.

The use of tissue analysis for crop diagnosis usually requires the establishment of critical nutrient concentrations, which are the lowest level of a nutrient required for optimum growth and maturation (Macy, 1936), below which nutrient deficiency may occur and above which sufficiency exists or luxury $\mathrm{N}$ consumption. The $\mathrm{N}$ concentration of the

Received for publication 18 Mar. 2002. Accepted for publication $31 \mathrm{Dec}$. 2002. This paper is a portion of a master's thesis submitted by S.M. Westerveld. We thank Kevin Vander Kooi, Cathy Bakker and the research station staff for their assistance. We also thank Dr. John Lauzon and Dr. John Warner for reviewing this paper. Funding provided by the Agricultural Adaptation Council through the support of the Ontario Fruit and Vegetable Grower's Association. ${ }^{1}$ Graduate Student, Dept. of Plant Agriculture.

${ }^{2}$ Associate Professor, Dept. of Plant Agriculture.

${ }^{3}$ Associate Professor, Dept. of Environmental Biology.

${ }^{4}$ Assistant Professor, Dept. of Plant Agriculture. lowest $\mathrm{N}$ rate that consistently maximizes economic yield is usually established as the critical N concentration (Macy, 1936; Ulrich, 1952; Munson and Nelson, 1973). Using the critical $\mathrm{N}$ concentration, one can use tissue deficiencies (Dow and Roberts, 1982).

Establishing critical $\mathrm{N}$ and $\mathrm{NO}_{3}-\mathrm{N}$ concentrations is complex due to the number of different variables that affect tissue nutrient concentrations in vegetable crops. In most crops, $\mathrm{N}$ concentrations in plant tissues decline over the growing season (Lorenz and Tyler, 1976; Greenwood et al., 1980; Sorensen, 2000). The tissue $\mathrm{N}$ and $\mathrm{NO}_{3}-\mathrm{N}$ levels obtained from tissue analysis also can vary greatly among different parts of the plant. Carrot leaf and root tissues, cauliflower curds and whole leaves, and cabbage midribs and whole leaves have been shown to differ by 20 (Warman and Havard, 1997) and 10 $\mathrm{g} \cdot \mathrm{kg}^{-1}$ (Piggott, 1986; Mills and Jones, 1996), respectively. Due to these effects, the sampling procedures have to be carefully matched with the references.

Other factors that affect nutrient concentrations include the location of the crop, climate, soil type, and cultivar or growth habit. Maier et al. (1990) showed critical total $\mathrm{N}$ concentrations in onion leaf blades range from 24 to $29 \mathrm{~g} \cdot \mathrm{kg}^{-1} \mathrm{~N}$ and 590 to $940 \mathrm{mg} \cdot \mathrm{kg}^{-1} \mathrm{NO}_{3}-\mathrm{N}$, between two locations. Location and climate had a major effect on leaf nutrient concentrations in tree fruits in Ontario (Archibald, 1964). In addition, the $\mathrm{NO}_{3}-\mathrm{N}$ concentration of two spinach types and the total $\mathrm{N}$ content analysis as a guide to detect and correct $\mathrm{N}$ of two collard cultivars were shown to differ by 6 and $4 \mathrm{~g} \cdot \mathrm{kg}^{-1}$, respectively (Maynard and Barker, 1974; Dangler and Wood, 1993). In Ontario, many newer cultivars and hybrids have been introduced since tissue analysis research was conducted.

Other variables that have been shown to affect nutrient concentrations include soil moisture content, air temperature, light intensity (Bates, 1971), fertilizer source, fertilizer application method (Barker et al., 1971), time of day (Steyn, 1961), plant moisture stress (Fisher, 1980), concentration of other nutrients, planting date, tillage practices, row spacing, plant population, chemical weed controls, and liming (Munson and Nelson, 1973). The combined effect of these variables makes the use of published critical nutrient concentrations challenging. As an example of the effect of these factors, published critical total $\mathrm{N}$ concentrations in onions range from $25 \mathrm{~g} \cdot \mathrm{kg}^{-1}$ (Piggott, 1986) to $40 \mathrm{~g} \cdot \mathrm{kg}^{-1}$ (Painter, 1977 in Caldwell et al., 1994) using the identical plant part and growth stage.

Growers and crop advisors in Ontario rely on published references, established outside of the province, in managing their fertilization practices with tissue analysis (Table 1). The references are inconsistent in the plant parts used, the stage of sampling, the preference for total $\mathrm{N}_{\text {or }} \mathrm{NO}_{3}-\mathrm{N}$, and in the critical $\mathrm{N}$ concentrations for similar plant parts and growth stages.

Cabbage, carrots, and onions, which are three of the most important vegetable crops in Ontario, are grown under a variety of soil and weather conditions. Given the varying effects that growth factors can have on tissue N levels, there is a need to evaluate the use of published critical $\mathrm{N}$ concentrations under local growing conditions and current production practices. The objectives of this research were to: 1) review the published critical $\mathrm{N}$ concentrations for onion, carrot, and cabbage; 2) determine if published critical $\mathrm{N}$ concentrations can be used effectively in Ontario for these crops; and, 3) to evaluate the effects of soil type, climate, and modern cultivars on critical $\mathrm{N}$ concentrations.

\section{Materials and Methods}

Nitrogen rate field studies were conducted on organic and mineral soils in 2000 and 2001 on cabbage, onions, and carrots. The experiments were conducted at the Univ. of Guelph-Muck Crops Research Station $\left(44^{\circ} 15^{\prime} \mathrm{N} 77^{\circ} 90^{\prime} \mathrm{W}\right)$, Bradford/Holland Marsh, Ontario (organic soil) and at the Univ. of Guelph-Simcoe Campus $\left(42^{\circ} 51^{\prime} \mathrm{N}\right.$ $80^{\circ} 16^{\prime} \mathrm{W}$ ), Simcoe, Ontario (mineral soil). Tissue samples were also collected from additional experiments, which were fertilized at recommended $\mathrm{N}$ application rates (Ontario Ministry of Agriculture, Food, and Rural Affairs (OMAFRA, 2000), see N rate studies), in both locations in 1999 and 2000 to supplement the results (McKeown and McDonald, unpublished data). The organic soil, a Hemic Histosol ( $\mathrm{pH}=6.5)$, contained high organic matter $(60 \%)$ and high moisture 
Table 1. Published critical nutrient concentrations $(\mathrm{CNC})$ of total nitrogen $(\mathrm{N})$ and nitrate- $\mathrm{N}\left(\mathrm{NO}_{3}-\mathrm{N}\right)$ for onions, carrots, and cabbage.

\begin{tabular}{|c|c|c|c|c|}
\hline Source & Time of sampling & Plant part & $\begin{array}{c}\text { Total N } \\
\mathrm{CNC}^{\mathrm{z}}\left(\mathrm{g} \cdot \mathrm{kg}^{-1}\right)\end{array}$ & $\begin{array}{c}\mathrm{NO}_{3}-\mathrm{N} \\
\mathrm{CNC}\left(\mathrm{mg} \cdot \mathrm{kg}^{-1}\right)\end{array}$ \\
\hline & & Onion & & \\
\hline \multirow[t]{3}{*}{ Maynard and Hochmuth (1997) } & early season & tallest leaf & 40 & --- \\
\hline & midseason & tallest leaf & 30 & --- \\
\hline & late season & tallest leaf & 25 & --- \\
\hline \multirow[t]{2}{*}{ Mills and Jones (1996) } & $1 / 3$ to $1 / 2$ maturity & whole tops & $50-60$ & --- \\
\hline & $1 / 2$ grown to maturity & whole tops & $45-55$ & --- \\
\hline \multirow[t]{2}{*}{ Piggott (1986) } & mid-growth & youngest mature leaf blade & $25-35$ & --- \\
\hline & bulbing & youngest mature leaf blade & --- & 2000 \\
\hline \multirow[t]{2}{*}{ Maier et al. (1990) } & $25-30 \mathrm{~mm}$ bulbs & youngest mature leaf blade & --- & $590-940$ \\
\hline & & Carrot & & \\
\hline Lorenz and Tyler (1976) & midgrowth & petiole of recently mature leaf & --- & 10,000 \\
\hline \multirow[t]{3}{*}{ Maynard and Hochmuth (1997) } & 60 days after seeding & petiole of recently mature leaf & 18 & --- \\
\hline & midgrowth & petiole of recently mature leaf & --- & 7500 \\
\hline & at harvest & petiole of recently mature leaf & 15 & --- \\
\hline \multirow[t]{2}{*}{ Mills and Jones (1996) } & midseason & new mature leaves & $21-35$ & --- \\
\hline & mature plants & oldest leaves & $30-35$ & --- \\
\hline \multirow[t]{3}{*}{ Piggott (1986) } & midgrowth & youngest mature leaf & 18 & --- \\
\hline & peak harvest & youngest mature leaf & 15 & --- \\
\hline & root thickening & petiole of youngest mature leaf & --- & 5000 \\
\hline & & abbage & & \\
\hline Lorenz and Tyler (1976) & at heading & midrib of wrapper leaf & --- & 9000 \\
\hline \multirow[t]{5}{*}{ Maynard and Hochmuth (1997) } & 5 weeks after planting & midrib of recently mature leaf & 32 & --- \\
\hline & 8 weeks after planting & midrib of recently mature leaf & 30 & --- \\
\hline & at heading & midrib of wrapper leaf & --- & 8000 \\
\hline & half grown heads & wrapper leaf & 30 & --- \\
\hline & at harvest & wrapper leaf & 18 & --- \\
\hline \multirow[t]{4}{*}{ Mills and Jones (1996) } & 2 to 6 weeks old & whole tops & $30-50$ & --- \\
\hline & 2 to 3 months old & wrapper leaf & $36-50$ & --- \\
\hline & mature plants & wrapper leaf & $30-48$ & --- \\
\hline & mature plants & midrib of wrapper leaf & $20-45$ & --- \\
\hline \multirow{3}{*}{ Piggott (1986) } & heading & wrapper leaf & 25 & --- \\
\hline & heading & heart leaf & --- & 5000 \\
\hline & peak harvest & wrapper leaf & 18 & --- \\
\hline \multirow[t]{2}{*}{ Huett and Rose (1989) } & 4 weeks after planting & youngest fully expanded leaf & 43.5 & 10,300 \\
\hline & 10 weeks after planting & youngest fully expanded leaf & --- & 4400 \\
\hline
\end{tabular}

${ }^{2}$ Reported as critical nutrient concentration or the lowest value of the sufficient or adequate range in the publication.

and nutrient holding capacity. The mineral soil ( $\mathrm{pH}=5.8-7.0)$, a Typic Hapludalf, had organic matter contents between $0.5 \%$ and $1.5 \%$ and low moisture and nutrient holding capacity. Temperature and rainfall records for 2000 and 2001 are presented in Table 2.

All tissue samples were oven dried $\left(70{ }^{\circ} \mathrm{C}\right.$ for $48 \mathrm{~h}$ ) and sent to A\&L Laboratories East, [London, Ontario (1999 and 2000)] and Univ. of Guelph Soil and Nutrient Laboratory, Guelph, Ontario (2001) for both $\mathrm{NO}_{3}-\mathrm{N}$ and total $\mathrm{N}$ analysis. The laboratory used direct combustion procedures and gas chromatography for tissue analysis. The results of tissue analyses for all studies were compared with critical $\mathrm{N}$ concentrations as published in the literature. Laboratory results were considered to be near the published critical concentration if they were within $3 \mathrm{~g} \cdot \mathrm{kg}^{-1} \mathrm{~N}$ or $300 \mathrm{mg} \cdot \mathrm{kg}^{-1}$ $\mathrm{NO}_{3}-\mathrm{N}$, considered to be above or below the critical concentration if they were within 3-15 $\mathrm{g} \cdot \mathrm{kg}^{-1} \mathrm{~N}$ or $300-1500 \mathrm{mg} \cdot \mathrm{kg}^{-1} \mathrm{NO}_{3}-\mathrm{N}$, and considered to be well above or well below the critical concentrations beyond these ranges. The crops for all experiments were considered to have a sufficient $\mathrm{N}$ concentration when higher $\mathrm{N}$ application rates did not result in a significant increase in yield.

Single cultivar experiments were arranged as a randomized complete-block design with four replications. Experiments containing more than one cultivar were arranged as splitplot designs with $\mathrm{N}$ as a main plot and cultivar as a sub-plot. Data were compared across the additional experiments using standard errors. Linear and quadratic regression analysis was performed on the effect of $\mathrm{N}$ application rate on tissue total $\mathrm{N}$ and $\mathrm{NO}_{3}-\mathrm{N}$ concentrations and yield within each $\mathrm{N}$ application rate study. Data were analyzed using the GLM and Univariate procedures of SAS version 8.0 (SAS Institute, Cary, N.C.). A type I error rate of 0.05 was set for all statistical tests.

\section{Cabbage}

Nitrogen rate study. Anitrogen application rate study was conducted on mineral soil in 2000 and 2001 using 'Atlantis', a midseason cultivar. Plants were transplanted on 9 June (2000) and 30 May (2001) into four-row plots, $7 \mathrm{~m} \mathrm{(2000)}$ and $9 \mathrm{~m}$ (2001) in length, with a between-row spacing of $75 \mathrm{~cm}$ and within

Table 2. Mean monthly air temperatures, monthly precipitation (Precip.), and long-term averages (LTA) at the Univ. of Guelph-Simcoe Campus and Muck Crops Research Station in 2000 and 2001.

\begin{tabular}{|c|c|c|c|c|c|c|c|c|c|c|c|c|}
\hline \multirow[b]{3}{*}{ Month } & \multicolumn{6}{|c|}{ Simcoe Campus } & \multicolumn{6}{|c|}{ Muck Crops Research Station } \\
\hline & \multicolumn{3}{|c|}{ Mean temp $\left({ }^{\circ} \mathrm{C}\right)$} & \multicolumn{3}{|c|}{ Precip. (mm) } & \multicolumn{3}{|c|}{ Mean temp $\left({ }^{\circ} \mathrm{C}\right)$} & \multicolumn{3}{|c|}{ Precip. (mm) } \\
\hline & 2000 & 2001 & $\mathrm{LTA}^{\mathrm{z}}$ & 2000 & 2001 & $\overline{\text { LTA }^{z}}$ & 2000 & 2001 & $\overline{\text { LTA }^{y}}$ & 2000 & 2001 & LTA $^{y}$ \\
\hline May & 14.4 & 14.7 & 12.6 & 103 & 109 & 74 & 13.1 & 13.9 & 12.9 & 160 & 85 & 70 \\
\hline June & 18.5 & 19.3 & 17.8 & 181 & 63 & 82 & 17.3 & 18.3 & 17.5 & 173 & 63 & 78 \\
\hline July & 19.8 & 20.7 & 20.4 & 146 & 11 & 77 & 18.4 & 18.9 & 20.3 & 86 & 60 & 82 \\
\hline Aug. & 19.7 & 21.8 & 19.5 & 81 & 105 & 80 & 18.3 & 20.6 & 19.0 & 76 & 32 & 84 \\
\hline Sept. & 15.8 & 15.9 & 15.5 & 99 & 37 & 89 & 14.2 & 14.7 & 14.6 & 80 & 53 & 84 \\
\hline
\end{tabular}

z30-year averages in Simcoe, Ontario.

${ }^{y} 10$-year averages at the Univ. of Guelph-Muck Crops Research Station. row spacing of $45 \mathrm{~cm}$. Nitrogen rates were $0 \%, 50 \%, 100 \%, 150 \%$, and $200 \%$ of the recommended $\mathrm{N}$ rate $\left(170 \mathrm{~kg} \cdot \mathrm{ha}^{-1} \mathrm{~N}\right.$ : split $75 \%$ preplant, $25 \%$ sidedress; OMAFRA, 2000). Nitrogen was applied in this and all rate experiments as calcium ammonium nitrate (CAN; $27.5 \% \mathrm{~N})$ preplant and potassium nitrate $(13.75 \% \mathrm{~N})$ for sidedress applications. At cupping, heading, and mature stages, a single wrapper leaf was collected from each of five plants at random from each of three replicates (four replicates at cupping in 2001) and submitted for tissue analysis. Total yield was assessed at maturity on 16 Aug., 30 Aug., and 11 Sept. (2000) and 17 Aug. and 5 Sept. (2001) from 4-m-long sections of the middle two rows of each plot. Yield data were expressed as total yield rather than marketable yield for all studies because other factors influenced marketable yield beyond treatment effects. 


\section{Onions}

Nitrogen source study. A nitrogen source study was conducted on organic soil in 1999 and 2000 using 'Hamlet' yellow cooking onions. Onions were direct seeded on $26 \mathrm{Apr}$. (1999) and 5 May (2000) into eight-row plots (two rows 'Hamlet' plus six guard rows), $5 \mathrm{~m}$ in length, spaced $42 \mathrm{~cm}$ between rows. Potassium nitrate, CAN, ammonium nitrate, urea, and calcium cyanamide were applied at the recommended rate of $90 \mathrm{~kg} \cdot \mathrm{ha}^{-1} \mathrm{~N}$ preplant (OMAFRA, 2000). A $0 \mathrm{~kg} \cdot \mathrm{ha}^{-1} \mathrm{~N}$ control was also included in the trials. Tissue samples were collected using 15 recently mature leaves from three replicates at the 5-leaf, bulbing and mature stages. Total yield was assessed for each cultivar at harvest on 15 Sept. (1999) and 18 Sept. (2000) from a $2.3 \mathrm{~m}$ long section of an inside row of each plot. To compare the tissue analysis data between the two years, tissue $\mathrm{N}$ concentrations were pooled among the $\mathrm{N}$ sources.

Nitrogen rate study. Nitrogen rate and timing trials were conducted on both organic and mineral soil in 2000 and 2001 using the yellow cooking onion 'Hamlet' on organic soil and the Spanish-type 'Winner' on mineral soil. Organic soil planting occurred as described for the $\mathrm{N}$ source study previously on 5 May (2000) and 7 May (2001). On mineral soil, plants were direct seeded on 14 June (2000) and transplanted 16 May (2001) into fourrow plots, $7 \mathrm{~m}$ (2000) and $6.5 \mathrm{~m}$ (2001) in length, spaced $75 \mathrm{~cm}$ apart, and with in-row spacing of $15 \mathrm{~cm}$. Nitrogen was applied at $0 \%, 100 \%$, and $200 \%$ of the locally recommended rates (organic soil $90 \mathrm{~kg} \cdot \mathrm{ha}^{-1} \mathrm{~N}$ all preplant; mineral soil $80 \mathrm{~kg} \cdot \mathrm{ha}^{-1} \mathrm{~N}$ preplant, $40 \mathrm{~kg} \cdot \mathrm{ha}^{-1} \mathrm{~N}$ sidedress; OMAFRA, 2000). In addition, two $\mathrm{N}$ timing treatments, based on the recommended rate, of $50 \%$ preplant plus $50 \%$ sidedress and $100 \%$ preplant plus three $33 \%$ sidedresses were tested in 2000 . Tissue samples were collected as described in the $\mathrm{N}$ source study for both soil types, except four replicates were tested at the 5-leaf stage in 2001. Total yield was assessed at harvest on 18 Sept. (2000) and 10 Sept. (2001) on organic soil as described previously, and on 16 Oct. from a 5-m section of an inside row of each plot (2000) and 21 Aug. from a 3.5 m section of the inside two rows of each plot (2001) on mineral soil.

\section{Additional data}

Cultivar study. A study was conducted on both organic and mineral soil in 2000 using transplanted Spanish onions, 'Candy' (Study; Cv-Candy) and 'Santos' (Study: Cv-Santos) in mineral soil, and direct seeded yellow cooking onions, 'Bastille' (Study: Cv-Bastille) and 'Hamlet' (Study: Cv-Hamlet) in organic soil (McKeown and McDonald, unpublished data). Nitrogen was adjusted to recommended rates (OMAFRA, 2000) using ammonium nitrate. Tissue samples were collected at the 5-leaf (both soil types), bulbing, and mature stages (organic soil only). All samples were collected from each cultivar as described in the $\mathrm{N}$ source study on all four replicates.

\section{Carrots}

Nitrogen rate study. A nitrogen rate study was conducted on carrots on both organic and mineral soil in 2000 and 2001 using 'Idaho' (2000) in the organic soil experiment and 'Annapolis' (2000) and 'Idaho' (2001) in the mineral soil experiment. Plants were direct seeded on 14 June (2000) and 13 June (2001) into mineral soil in three row plots, $7 \mathrm{~m}$ in length, spaced $35 \mathrm{~cm}$ between rows, with three guard rows between plots, and on 28 July (2000) and 24 May (2001) into organic soil in four hill plots (two hills 'Idaho'), $5 \mathrm{~m}$ in length, $20 \mathrm{~cm}$ high, spaced $86 \mathrm{~cm}$ between hills. Nitrogen was applied at $0 \%, 50 \%, 100 \%$, $150 \%$, and $200 \%$ of the recommended rate $(60$ $\mathrm{kg} \cdot \mathrm{ha}^{-1} \mathrm{~N}$ preplant on organic soil; $110 \mathrm{~kg} \cdot \mathrm{ha}^{-1}$ $\mathrm{N}$ preplant $35 \mathrm{~kg} \cdot \mathrm{ha}^{-1} \mathrm{~N}$ sidedress on mineral soil; OMAFRA, 2000). Petiole samples were collected early season, midseason, and late season using the petioles of 30 recently mature leaves from each of three replicates on each soil type (four replicates early season in 2001). Total yield was assessed at harvest on 6 Nov. (2000) and 24 Oct. (2001) for mineral soil plots from $2 \mathrm{~m}$ sections of each row and 17 Nov. (2000) and 25 Oct. (2001) from $2.3 \mathrm{~m}$ of an inside row for organic soil plots.

\section{Results}

\section{Cabbage}

In the cabbage N rate study, the relationship between $\mathrm{N}$ application rate and tissue total $\mathrm{N}$ concentration was generally linear but not always significant and the relationship was quadratic at the cupping stage in 2001 (Table 3 ). Total $\mathrm{N}$ concentrations in the rate study were below the published critical concentration at cupping, above the critical $\mathrm{N}$ concentration at heading (except $0 \mathrm{~N}$ rate) and were within the published critical range at the mature stage at all $\mathrm{N}$ application rates in 2000 (Table 4). In 2001 , the total $\mathrm{N}$ concentrations at all $\mathrm{N}$ rates were at or above or well above the critical concentrations at cupping and heading, except for the $0 \mathrm{~N}$ rate at cupping (Table 4), and were within the published range at maturity. Average total $\mathrm{N}$ concentrations in 2001 were higher than 2000 at the same $\mathrm{N}$ application rate and sampling stage (Table 4).

In the cabbage $\mathrm{N}$ rate study, the relationship between $\mathrm{N}$ application rate and tissue $\mathrm{NO}_{3}$ $\mathrm{N}$ was nonsignificant at the cupping stage in 2000 , but the relationship was quadratic at the cupping stage in 2001, and linear at the heading and mature stages in both years (Table 3). $\mathrm{NO}_{3}-\mathrm{N}$ concentrations were well above the critical concentration at the cupping stage and below or well below at heading and maturity in all treatments in 2000 (Table 4). In 2001, $\mathrm{NO}_{3}-\mathrm{N}$ concentrations were below or well below the published critical concentration at all $\mathrm{N}$ rates and sampling stages, except the highest $\mathrm{N}$ rates at maturity (Table 4). Tissue $\mathrm{NO}_{3}-\mathrm{N}$ concentrations in 2000 were much higher at the cupping stage than they were in the 2001 trial, but at heading and maturity differences were minimal (Table 4).
A significant quadratic relationship between $\mathrm{N}$ application rate and yield was found in the $\mathrm{N}$ rate study in 2000 (Table 4), with a maximum at $155 \%$ of the recommended $\mathrm{N}$ application rate $\left(280 \mathrm{~kg} \cdot \mathrm{ha}^{-1} \mathrm{~N}\right)$. No significant effect of $\mathrm{N}$ rate on yield was found in 2001.

\section{Onions}

In the $\mathrm{N}$ rate study, the relationship between N application rate and tissue total $N$ concentrations was generally linear, but was not always significant (Table 3). A quadratic relationship was found at the 5-leaf stage on organic soil in 2001 (Table 3). In 2000, at the 5-leaf stage, total $\mathrm{N}$ concentrations were below the critical nutrient concentration at all rates except the highest $\mathrm{N}$ rate on organic soil (Table 5). In all other sampling dates and in both years total $\mathrm{N}$ concentrations were near or above the critical $\mathrm{N}$ concentrations (Table 5).

The relationship between $\mathrm{N}$ application rate and $\mathrm{NO}_{3}-\mathrm{N}$ concentration in leaves in the $\mathrm{N}$ rate study was generally linear (Table 3 ). However the relationship was not always significant, and was quadratic at the early sampling stage on mineral soil in 2001 (Table 3). Tissue $\mathrm{NO}_{3}-\mathrm{N}$ concentrations were mostly below the critical concentration at the bulbing stage in all plots and treatments. Differences in soil type did not appear to affect $\mathrm{NO}_{3}-\mathrm{N}$ concentrations in leaves in either year (Table 5). Results in 2001 were higher than 2000 results at the 5-leaf stage in both soil types.

In the $\mathrm{N}$ rate study, yield was unaffected by $\mathrm{N}$ application rate or timing in both soil types and years (Table 5).

Tissue total $\mathrm{N}$ concentrations in onions at the recommended $\mathrm{N}$ application rate were below the published critical $N$ concentration at the 5-leaf stage in both additional onion studies except for 'Bastille' plants in the cultivar study. Total $\mathrm{N}$ concentrations were generally near or above the critical concentration at the bulbing and mature stages (Table 6). Total $\mathrm{N}$ was higher in 2000 than in 1999 in the $\mathrm{N}$ source study (Table 6). Cultivars showed differences in total $\mathrm{N}$ concentration within each soil type, and were higher in onions grown on organic soil than mineral soil (Table 6). 'Bastille' and 'Hamlet' did not differ at the bulbing and mature sampling stages.

$\mathrm{NO}_{3}-\mathrm{N}$ concentrations in the additional onion studies were near the published critical nutrient concentration in the cultivar study at the bulbing stage on organic soil (Table 6), but were below the critical level at the mature stage. 'Candy' had higher tissue $\mathrm{NO}_{3}-\mathrm{N}$ concentrations than 'Santos' at the 5-leaf stage. 'Hamlet' had higher $\mathrm{NO}_{3}-\mathrm{N}$ concentrations than 'Bastille' at the 5-leaf stage, but lower tissue $\mathrm{NO}_{3}-\mathrm{N}$ at the bulbing and mature stages. Concentrations of $\mathrm{NO}_{3}-\mathrm{N}$ were higher in onions grown on organic soil than mineral soil at the 5-leaf stage (Table 6).

\section{Carrots}

The relationship between tissue total $\mathrm{N}$ concentrations and $\mathrm{N}$ application rate in the $\mathrm{N}$ rate study was generally linear, but the 
Table 3. Regression of nitrogen $(\mathrm{N})$ rate and tissue test total $\mathrm{N}$ and nitrate $\left(\mathrm{NO}_{3}-\mathrm{N}\right)$ concentrations from cabbage, carrots, and onions grown on organic and mineral soil in Ontario in 2000 and 2001.

\begin{tabular}{|c|c|c|c|c|c|c|c|}
\hline \multirow[b]{2}{*}{ Soil } & \multirow[b]{2}{*}{ Stage } & \multicolumn{3}{|c|}{ Total N $\left(\mathrm{g} \cdot \mathrm{kg}^{-1}\right)$} & \multicolumn{3}{|c|}{$\mathrm{NO}_{3}-\mathrm{N}\left(\mathrm{mg} \cdot \mathrm{kg}^{-1}\right)$} \\
\hline & & $P$ & $R^{2}$ & Equation $^{z}$ & $P$ & $R^{2}$ & Equation $^{2}$ \\
\hline \multicolumn{8}{|l|}{ Cabbage Mineral } \\
\hline \multirow[t]{3}{*}{2000} & Cupping & 0.22 & 0.21 & $\mathrm{~T}_{\mathrm{N}}=33.4$ & 0.52 & 0.05 & $\mathrm{~T}_{\mathrm{NA}}=20,707$ \\
\hline & Heading & $<0.01$ & 0.60 & $\mathrm{~T}_{\mathrm{N}}^{\mathrm{N}}=25.1+0.056 \mathrm{~A}$ & $<0.01$ & $0.55^{y}$ & $\mathrm{~T}_{\mathrm{NA}}^{\mathrm{NA}}=1142+14.94 \mathrm{~A}$ \\
\hline & Mature & $<0.01$ & $0.74^{y}$ & $\mathrm{~T}_{\mathrm{N}}^{\mathrm{N}}=23.0+0.045 \mathrm{~A}$ & $<0.01$ & $0.66^{y}$ & $\mathrm{~T}_{\mathrm{NA}}^{\mathrm{NA}}=720+14.13 \mathrm{~A}$ \\
\hline \multirow[t]{3}{*}{2001} & Cupping & $<0.01$ & 0.61 & $\mathrm{~T}_{\mathrm{N}}^{\mathrm{N}}=37.3+0.145 \mathrm{~A}-0.00055 \mathrm{~A}^{2}$ & $<0.01$ & 0.65 & $\mathrm{~T}_{\mathrm{NA}}^{\mathrm{NA}}=3500+62.54 \mathrm{~A}-0.2061 \mathrm{~A}^{2}$ \\
\hline & Heading & $<0.01$ & 0.60 & $\mathrm{~T}_{\mathrm{N}}=28.8+0.082 \mathrm{~A}$ & $<0.01$ & 0.60 & $\mathrm{~T}_{\mathrm{NA}}^{\mathrm{NA}}=2291+24.63 \mathrm{~A}$ \\
\hline & Mature & $<0.01$ & 0.62 & $\mathrm{~T}_{\mathrm{N}}=26.9+0.068 \mathrm{~A}$ & $<0.01$ & 0.76 & $\mathrm{~T}_{\mathrm{NA}}^{\mathrm{NA}}=1090+20.99 \mathrm{~A}$ \\
\hline \multicolumn{8}{|l|}{ Onion Organic } \\
\hline \multirow[t]{3}{*}{2000} & 5-leaf & 0.02 & 0.54 & $\mathrm{~T}_{\mathrm{N}}=33.5+0.040 \mathrm{~A}$ & 0.01 & 0.40 & $\mathrm{~T}_{\mathrm{NA}}=818+7.58 \mathrm{~A}$ \\
\hline & Bulbing & $<0.01$ & 0.30 & $\mathrm{~T}_{\mathrm{N}}^{\mathrm{N}}=31.3+0.025 \mathrm{~A}$ & $<0.01$ & $0.82^{y}$ & $\mathrm{~T}_{\mathrm{NA}}^{\mathrm{NA}}=982+5.01 \mathrm{~A}$ \\
\hline & Mature & 0.31 & 0.04 & $\mathrm{~T}_{\mathrm{N}}^{\mathrm{N}}=33.0$ & 0.99 & 0.00 & $\mathrm{~T}_{\mathrm{NA}}^{\mathrm{NA}}=383$ \\
\hline \multirow[t]{3}{*}{2001} & 5-leaf & 0.02 & 0.60 & $\mathrm{~T}_{\mathrm{N}}^{\mathrm{N}}=43.7+0.049 \mathrm{~A}-0.00070 \mathrm{~A}^{2}$ & 0.70 & 0.02 & $\mathrm{~T}_{\mathrm{NA}}^{\mathrm{NA}}=5320$ \\
\hline & Bulbing & 1.00 & 0.00 & $\mathrm{~T}_{\mathrm{N}}^{\mathrm{N}}=37.7$ & 0.99 & 0.00 & $\mathrm{~T}_{\mathrm{NA}}^{\mathrm{NA}}=1597$ \\
\hline & Mature & 0.17 & 0.25 & $\mathrm{~T}_{\mathrm{N}}^{\mathrm{N}}=26.7$ & 0.06 & 0.60 & $\mathrm{~T}_{\mathrm{NA}}^{\mathrm{NA}}=359$ \\
\hline \multicolumn{8}{|l|}{ Onion Mineral } \\
\hline \multirow[t]{3}{*}{2000} & 5-leaf & 0.22 & 0.22 & $\mathrm{~T}_{\mathrm{N}}=32.7$ & 0.06 & 0.59 & $\mathrm{~T}_{\mathrm{NA}}=1799$ \\
\hline & Bulbing & 0.02 & 0.63 & $\mathrm{~T}_{\mathrm{N}}^{\mathrm{N}}=31.7+0.023 \mathrm{~A}$ & $0.03^{x}$ & 0.53 & $\mathrm{~T}_{\mathrm{NA}}^{\mathrm{NA}}=180+5.66 \mathrm{~A}$ \\
\hline & Mature & 0.05 & 0.45 & $\mathrm{~T}_{\mathrm{N}}^{\mathrm{N}}=26.5+0.022 \mathrm{~A}$ & 0.06 & 0.47 & $\mathrm{~T}_{\mathrm{NA}}^{\mathrm{NA}}=310$ \\
\hline \multirow[t]{3}{*}{2001} & 5-leaf & $0.01^{\mathrm{x}}$ & 0.50 & $\mathrm{~T}_{\mathrm{N}}=34.6+0.053 \mathrm{~A}$ & $<0.01$ & 0.94 & $\mathrm{~T}_{\mathrm{NA}}^{\mathrm{NA}}=517+49.08 \mathrm{~A}-0.1453 \mathrm{~A}^{2}$ \\
\hline & Bulbing & 0.10 & 0.34 & $\mathrm{~T}_{\mathrm{N}}^{\mathrm{N}}=36.0$ & 0.09 & 0.35 & $\mathrm{~T}_{\mathrm{NA}}^{\mathrm{NA}}=1430$ \\
\hline & Mature & $<0.01$ & $0.89^{y}$ & $\mathrm{~T}_{\mathrm{N}}^{\mathrm{N}}=28.5+0.028 \mathrm{~A}$ & $<0.01$ & 0.77 & $\mathrm{~T}_{\mathrm{NA}}^{\mathrm{NA}}=53.71+10.12 \mathrm{~A}$ \\
\hline \multicolumn{8}{|l|}{ Carrot Organic } \\
\hline \multirow[t]{2}{*}{2000} & Early & 0.02 & 0.47 & $\mathrm{~T}_{\mathrm{N}}=15.9+0.021 \mathrm{~A}$ & $<0.01$ & 0.62 & $\mathrm{~T}_{\mathrm{NA}}=3251+12.95 \mathrm{~A}$ \\
\hline & Midseason & 0.16 & 0.21 & $\mathrm{~T}_{\mathrm{N}}^{\mathrm{N}}=13.0$ & 0.18 & 0.19 & $\mathrm{~T}_{\mathrm{NA}}^{\mathrm{NA}}=898$ \\
\hline \multirow[t]{3}{*}{2001} & Early & 0.26 & 0.15 & $\mathrm{~T}_{\mathrm{N}}^{\mathrm{N}}=21.4$ & 0.25 & 0.15 & $\mathrm{~T}_{\mathrm{NA}}^{\mathrm{NA}}=10,814$ \\
\hline & Midseason & 0.93 & $0.00^{y}$ & $\mathrm{~T}_{\mathrm{N}}=15.4$ & 0.57 & 0.03 & $\mathrm{~T}_{\mathrm{NA}}^{\mathrm{NA}}=4937$ \\
\hline & Late & 0.04 & 0.43 & $\mathrm{~T}_{\mathrm{N}}^{\mathrm{N}}=11.6-0.022 \mathrm{~A}-0.00012 \mathrm{~A}^{2}$ & 0.52 & 0.10 & $\mathrm{~T}_{\mathrm{NA}}^{\mathrm{NA}}=1437$ \\
\hline \multicolumn{8}{|l|}{ Carrot Mineral } \\
\hline \multirow[t]{3}{*}{2000} & Early & $<0.01$ & 0.76 & $\mathrm{~T}_{\mathrm{N}}=16.9+0.047 \mathrm{~A}$ & $<0.01$ & 0.78 & $\mathrm{~T}_{\mathrm{NA}}=3873+40.49 \mathrm{~A}$ \\
\hline & Midseason & $<0.01$ & 0.75 & $\mathrm{~T}_{\mathrm{N}}^{\mathrm{N}}=7.3+0.027 \mathrm{~A}$ & $<0.01$ & 0.85 & $\mathrm{~T}_{\mathrm{NA}}^{\mathrm{NA}}=301+17.78 \mathrm{~A}$ \\
\hline & Late & $<0.01$ & 0.54 & $\mathrm{~T}_{\mathrm{N}}=6.5+0.021 \mathrm{~A}$ & $<0.01$ & $0.64^{y}$ & $\mathrm{~T}_{\mathrm{NA}}^{\mathrm{NA}}=59+8.27 \mathrm{~A}$ \\
\hline \multirow[t]{3}{*}{2001} & Early & 0.02 & 0.36 & $\mathrm{~T}_{\mathrm{N}}^{\mathrm{N}}=7.9+0.052 \mathrm{~A}-0.00019 \mathrm{~A}^{2}$ & $<0.01$ & 0.48 & $\mathrm{~T}_{\mathrm{NA}}^{\mathrm{NA}}=680+6.64 \mathrm{~A}$ \\
\hline & Midseason & $<0.01$ & 0.83 & $\mathrm{~T}_{\mathrm{N}}^{\mathrm{N}}=7.6+0.021 \mathrm{~A}$ & $<0.01$ & $0.81^{\mathrm{y}}$ & $\mathrm{T}_{\mathrm{NA}}^{\mathrm{NA}}=78.49+3.50 \mathrm{~A}$ \\
\hline & Late & $<0.01^{\mathrm{x}}$ & 0.59 & $\mathrm{~T}_{\mathrm{N}}^{\mathrm{N}}=8.1+0.013 \mathrm{~A}$ & $<0.01$ & 0.48 & $\mathrm{~T}_{\mathrm{NA}}^{\mathrm{NA}}=3.74+1.28 \mathrm{~A}$ \\
\hline
\end{tabular}

${ }^{2} \mathrm{~T}_{\mathrm{N}}=$ tissue total nitrogen; $\mathrm{T}_{\mathrm{NA}}=$ tissue total $\mathrm{NO}_{3}-\mathrm{N} ; \mathrm{A}=\%$ of OMAFRA (Ontario Ministry of Agriculture, Food, and Rural Affairs) recommended $\mathrm{N}$ application rate.

${ }^{y}$ One outlier removed in the regression analysis.

${ }^{x}$ Analysis of variance is nonsignificant.

relationship was not always significant and there was a quadratic relationship at the early growth stage on mineral soil (Table 3 ). At the early sampling stage in 2000 , total $\mathrm{N}$ concentrations were near the critical concentration at all $\mathrm{N}$ rates on organic soil and the lowest two $\mathrm{N}$ rates on mineral soil, and were above the critical concentration at rates above $50 \%$ of the recommended rate on mineral soil (Table 7). In 2001 , at the early stage, total $\mathrm{N}$ concentrations were at or above the critical concentration for all $\mathrm{N}$ rates on organic soil, and below the critical concentration for all $\mathrm{N}$ rates on mineral soil. At the mid- and late-season sampling stages, all
Table 4. Total nitrogen $(\mathrm{N})$ and nitrate $\left(\mathrm{NO}_{3}-\mathrm{N}\right)$ concentrations of cabbage grown on mineral soil in Ontario in 2000 and 2001 as affected by rate of $\mathrm{N}$ application.

\begin{tabular}{|c|c|c|c|c|c|c|c|c|}
\hline \multicolumn{2}{|c|}{$\begin{array}{c}\mathrm{N} \text { application rate } \\
\left(\mathrm{kg} \cdot \mathrm{ha}^{-1}\right)^{\mathrm{z}}\end{array}$} & \multicolumn{3}{|c|}{$\begin{array}{c}\text { Tissue total N concn } \\
\left(\mathrm{g} \cdot \mathrm{kg}^{-1}\right)^{\mathrm{y}}\end{array}$} & \multicolumn{3}{|c|}{$\begin{array}{c}\text { Tissue } \mathrm{NO}_{3}-\mathrm{N} \text { concn } \\
\left(\mathrm{mg} \cdot \mathrm{kg}^{-1}\right)^{\mathrm{y}}\end{array}$} & \multirow{2}{*}{$\begin{array}{l}\text { Yield } \\
\left(\mathrm{t} \cdot \mathrm{ha}^{-1}\right)^{\mathrm{x}}\end{array}$} \\
\hline Preplant & Sidedress & Cupping & Heading & Mature & Cupping & Heading & Mature & \\
\hline & & & & 2000 & & & & \\
\hline 0 & 0 & 30 & 24 & 27 & 16,291 & 1100 & 624 & 36.3 \\
\hline 64 & 21 & 33 & 30 & 26 & 21,854 & 1694 & 1104 & 63.6 \\
\hline 128 & 42 & 32 & 29 & 28 & 20,539 & 2668 & 2121 & 62.7 \\
\hline 192 & 63 & 35 & 36 & 29 & 22,234 & 5558 & 2643 & 69.3 \\
\hline \multirow[t]{2}{*}{256} & 84 & 37 & 35 & 32 & 22,618 & 3650 & 3778 & 69.6 \\
\hline & & & & 2001 & & & & \\
\hline 0 & 0 & 37 & 27 & 26 & 3501 & 1362 & 986 & 59.2 \\
\hline 64 & 21 & 44 & 35 & 31 & 6182 & 4093 & 2135 & 63.8 \\
\hline 128 & 42 & 46 & 39 & 35 & 7476 & 5395 & 3138 & 57.9 \\
\hline 192 & 63 & 46 & 41 & 38 & 8463 & 6705 & 4763 & 70.5 \\
\hline 256 & 84 & 45 & 44 & 39 & 7690 & 6213 & 4920 & 58.1 \\
\hline $\mathrm{CNCs}^{\mathrm{w}}$ & & 43.5 & 25 & $18-48$ & 10,300 & $8000-9000$ & 4400 & \\
\hline
\end{tabular}

${ }^{\mathrm{z}}$ Correspond with $0 \%, 50 \%, 100 \%, 150 \%$, and $200 \%$ of the OMAFRA (Ontario Ministry of Agriculture, Food, and Rural Affairs) recommended $\mathrm{N}$ application rate.

${ }^{\mathrm{y}}$ Regression statistics presented in Table 3; $\mathrm{n}=3$ for all but the cupping stage in $2001(\mathrm{n}=4)$.

×2000 Regression: $P=0.0003, R^{2}=0.61, \mathrm{Y}=39.16+0.4114 \mathrm{~A}-0.00133 \mathrm{~A}^{2}, \mathrm{Y}=$ total yield, $\mathrm{A}=\%$ of OMAFRA recommended $\mathrm{N}$ application rate; 2001 Regression and analysis of variance are nonsignificant.

wPublished critical nutrient concentrations (CNC) from Table 1 applicable to the stage of sampling and plant parts used for the analysis.
$\mathrm{N}$ application rates in both soil types and years exhibited deficient total $\mathrm{N}$ concentrations when compared to the published critical concentrations except for carrots grown on organic soil at the midseason stage, which were near the published range (Table 7).

The relationship between $\mathrm{NO}_{3}-\mathrm{N}$ concentrations and $\mathrm{N}$ application rate in the carrot $\mathrm{N}$ rate study was generally linear in both soil types and years, except on mineral soil in 2001 where there was no significant relationship (Table 3). At the midseason sampling stage, $\mathrm{NO}_{3}-\mathrm{N}$ concentrations were well below the critical $\mathrm{N}$ concentrations in both soil types and years (Table 7). $\mathrm{NO}_{3}-\mathrm{N}$ concentrations were significantly higher on mineral soil than on organic soil both early and midseason in 2000 , but were significantly lower on mineral soil than organic soil in 2001 (Table 7).

Yield was not affected by $\mathrm{N}$ application rate in both soil types and years in the $\mathrm{N}$ rate study (Table 7).

\section{Discussion}

Tissue $\mathrm{NO}_{3}-\mathrm{N}$ levels in onions, carrots, and cabbage were variable, and did not match published critical nutrient concentrations in most cases. An $\mathrm{N}$ deficiency occurred in the cabbage experiment below $165 \%$ of the recommended rate in 2000 according to the 
Table 5. Total nitrogen $(\mathrm{N})$ and nitrate- $\mathrm{N}\left(\mathrm{NO}_{3}-\mathrm{N}\right)$ concentrations at 3 sampling stages of onions grown on organic and mineral soil in Ontario in 2000 and 2001 as affected by rate and timing of $\mathrm{N}$ application.

\begin{tabular}{|c|c|c|c|c|c|c|c|c|}
\hline \multicolumn{2}{|c|}{$\begin{array}{c}\mathrm{N} \text { application } \text { rate }^{\mathrm{z}} \\
\left(\mathrm{kg} \cdot \mathrm{ha}^{-1}\right)\end{array}$} & \multicolumn{3}{|c|}{$\begin{array}{l}\text { Tissue total } \mathrm{N} \text { conc. } \\
\qquad\left(\mathrm{g} \cdot \mathrm{kg}^{-1}\right)\end{array}$} & \multicolumn{3}{|c|}{$\begin{array}{l}\text { Tissue } \mathrm{NO}_{3}-\mathrm{N} \text { conc. }{ }^{y} \\
\left(\mathrm{mg} \cdot \mathrm{kg}^{-1}\right)\end{array}$} & \multirow{2}{*}{$\begin{array}{l}\text { Yield }^{\mathrm{x}} \\
\left(\mathrm{t} \cdot \mathrm{ha}^{-1}\right) \\
\end{array}$} \\
\hline Preplant & Sidedress & 5-leaf & Bulbing & Mature & $\overline{\text { 5-leaf }}$ & Bulbing & Mature & \\
\hline \multicolumn{9}{|c|}{ 2000-Organic } \\
\hline 0 & 0 & 35 & 31 & 32 & 895 & 907 & 312 & 40.9 \\
\hline 45 & 45 & 38 & 33 & 34 & 2410 & 1485 & 596 & 40.4 \\
\hline 90 & 0 & 38 & 33 & 33 & 2180 & 1720 & 468 & 42.0 \\
\hline 90 & 90 & 37 & 31 & 32 & 1553 & 853 & 336 & 43.1 \\
\hline 180 & 0 & 42 & 35 & 34 & 2158 & 1977 & 369 & 41.4 \\
\hline \multicolumn{9}{|c|}{ 2000-Mineral } \\
\hline 0 & 0 & 30 & 31 & 27 & 658 & 181 & 75 & 9.4 \\
\hline 60 & 60 & 37 & 37 & 31 & 3102 & 1862 & 378 & 14.9 \\
\hline 80 & 40 & 32 & 35 & 28 & 1797 & 744 & 278 & 7.4 \\
\hline 120 & 120 & 35 & 35 & 30 & 2651 & 1435 & 376 & 11.1 \\
\hline 160 & 80 & 36 & 36 & 31 & 2941 & 1222 & 576 & 9.7 \\
\hline \multicolumn{9}{|c|}{ 2001-Organic } \\
\hline 0 & 0 & 44 & 37 & 27 & 5202 & 1539 & 354 & 98.0 \\
\hline 90 & 0 & 44 & 38 & 27 & 5368 & 1708 & 290 & 80.5 \\
\hline 180 & 0 & 42 & 37 & 26 & 5391 & 1544 & 432 & 92.8 \\
\hline \multicolumn{9}{|c|}{ 2001-Mineral } \\
\hline 0 & 0 & 34 & 34 & 29 & 517 & 829 & 192 & 18.2 \\
\hline 80 & 40 & 41 & 37 & 31 & 3971 & 1833 & 790 & 16.9 \\
\hline 160 & 80 & 45 & 37 & 32 & 4519 & 1628 & 2216 & 16.4 \\
\hline $\mathrm{CNCs}^{\mathrm{w}}$ & & 40 & $25-35$ & 25 & --- & 2000 & --- & \\
\hline
\end{tabular}

${ }^{2}$ Correspond with $0 \%, 100 \%$, and $200 \%$ of the current OMAFRA(Ontario Ministry of Agriculture, Food, and Rural Affairs) recommended $\mathrm{N}$ application rate, with two additional timing treatments in 2000. ${ }^{y}$ Regression statistics presented in Table 3; $n=3$ for all but the 5-leaf stage in $2001(n=4)$.

${ }^{x}$ Regression and analysis of variance are nonsignificant in either soil type.

wPublished critical nutrient concentrations from Table 1 applicable to the stage of sampling and plant parts used for the analysis. definition of Lorenz and Tyler (1976) who suggested an $\mathrm{N}$ deficiency occurs when crop yield responds to an increase in $\mathrm{N}$ application. However, a comparison with published critical $\mathrm{NO}_{3}-\mathrm{N}$ concentrations showed all treatments to have sufficient $\mathrm{NO}_{3}-\mathrm{N}$ concentrations at cupping, and deficient $\mathrm{NO}_{3}-\mathrm{N}$ at heading and maturity in 2000. In 2001, cabbage yields did not respond to $\mathrm{N}$ application rates, but $\mathrm{NO}_{3}-$ $\mathrm{N}$ concentrations were well below published critical concentrations at all sampling stages. In both onions and carrots, $\mathrm{NO}_{3}-\mathrm{N}$ concentrations were below the published critical concentrations, but increasing the $\mathrm{N}$ rate did not increase yields. Anyone using the critical $\mathrm{NO}_{3}-\mathrm{N}$ concentrations in these crops would assume an $\mathrm{N}$ deficiency, which could result in both wasteful and environmentally damaging $\mathrm{N}$ application. Our results confirmed the

reports of Zink (1966) who showed $\mathrm{NO}_{3}-\mathrm{N}$ concentrations in onions to be highly variable, and not a reliable determination of $\mathrm{N}$. Barker et al. (1971), working with urea and ammonium nitrate sources, reported that $\mathrm{NO}_{3}-\mathrm{N}$ accumulation in spinach was related to the $\mathrm{NO}_{3}-\mathrm{N}$ supplied in the fertilizer, which introduces an additional variable in the establishment of critical $\mathrm{NO}_{3}-\mathrm{N}$ concentrations. With the high variability in tissue $\mathrm{NO}_{3}-\mathrm{N}$ concentrations in all three crops, and the low availability of published critical $\mathrm{NO}_{3}-\mathrm{N}$ concentrations, laboratory tissue $\mathrm{NO}_{3}-\mathrm{N}$ analysis does not currently provide much useful information. Future research on critical $\mathrm{NO}_{3}-\mathrm{N}$ concentrations for Ontario conditions is required.

Tissue total $\mathrm{N}$ concentration analysis results did not consistently match the published critical concentrations, but were much closer

Table 6. Total nitrogen $(\mathrm{N})$ and nitrate- $\mathrm{N}\left(\mathrm{NO}_{3}-\mathrm{N}\right)$ concentrations of onion from recently mature leaves grown on organic and mineral soil in Ontario in 1999 and 2000 with $\mathrm{N}^{2}$ applied at the OMAFRA recommended $\mathrm{N}$ application rate.

\begin{tabular}{|c|c|c|c|c|c|c|c|}
\hline \multirow[b]{2}{*}{ Study } & \multirow[b]{2}{*}{$\mathrm{n}$} & \multicolumn{3}{|c|}{ Tissue total $\mathrm{N}$ concn $\left(\mathrm{g} \cdot \mathrm{kg}^{-1}\right)^{y}$} & \multicolumn{3}{|c|}{ Tissue $\mathrm{NO}_{3}-\mathrm{N}$ concn $\left(\mathrm{mg} \cdot \mathrm{kg}^{-1}\right)^{\mathrm{y}}$} \\
\hline & & 5-leaf & Bulbing & Mature & 5-leaf & Bulbing & Mature \\
\hline \multicolumn{8}{|c|}{ Organic-1999 } \\
\hline $\mathrm{N}$ source & 15 & $33 \pm 0.5$ & $29 \pm 0.6$ & $25 \pm 0.8$ & --- & --- & --- \\
\hline \multicolumn{8}{|c|}{ Organic-2000 } \\
\hline $\mathrm{N}$ source & 15 & $37 \pm 0.7$ & $34 \pm 0.4$ & $33 \pm 0.4$ & $2210 \pm 295$ & $1740 \pm 122$ & $520 \pm 38$ \\
\hline Cv-Hamlet & 30 & $38 \pm 0.3$ & $39 \pm 0.5$ & $31 \pm 0.3$ & $4460 \pm 138$ & $2080 \pm 99$ & $140 \pm 14$ \\
\hline Cv-Bastille & 30 & $48 \pm 0.6$ & $38 \pm 0.5$ & $28 \pm 0.4$ & $3220 \pm 138$ & $2550 \pm 100$ & $370 \pm 35$ \\
\hline \multicolumn{8}{|c|}{ Mineral-2000 } \\
\hline Cv-Candy & 40 & $31 \pm 0.3$ & --- & --- & $1460 \pm 85$ & --- & --- \\
\hline Cv-Santos & 40 & $27 \pm 0.3$ & --- & --- & $920 \pm 67$ & --- & --- \\
\hline $\mathrm{CNCs}^{\mathrm{x}}$ & & 40 & $25-35$ & 25 & --- & 2000 & $590-940$ \\
\hline
\end{tabular}

${ }^{2}$ Ontario Ministry of Agriculture, Food, and Rural Affairs

${ }^{y}$ Data presented as mean \pm standard error.

xPublished critical nutrient concentrations from Table 1 applicable to the stage of sampling and plant parts used for the analysis. than the $\mathrm{NO}_{3}-\mathrm{N}$ analysis. Yields confirmed the critical nutrient concentration comparison in most of the onion data, except at the 5-leaf stage on both soil types in 2000 and on mineral soil in 2001. In carrots, however, yield data supported the comparison of total $\mathrm{N}$ concentrations with published critical concentrations only in organic soil in 2001 in the early and midseason sampling stages. In the cases where yields did not support the critical concentrations for both onions and carrots, comparisons to the published critical concentrations suggested an $\mathrm{N}$ deficiency even though yield did not increase with increasing $\mathrm{N}$ rate. This would result in over application of $\mathrm{N}$ fertilizer, and could result in reduced yields, especially in carrots. Studies have shown that carrot yields often do not respond to increasing $\mathrm{N}$ application rate (Warncke, 1996), so $\mathrm{N}$ deficiencies should not be occurring at any growth stage in these cases. Late cabbage often responds to $\mathrm{N}$ rates well above the rates tested in this study (Zebarth et al., 1991; Freyman et al., 1991), but in the final two sampling stages in 2000 , the critical nutrient concentrations showed sufficient levels of total $\mathrm{N}$ at all $\mathrm{N}$ application rates. Anyone using the critical total $\mathrm{N}$ concentrations for cabbage would assume their crop had sufficient total $\mathrm{N}$ concentrations, but would suffer a loss of potential yield because of an undetected $\mathrm{N}$ deficiency. If critical total $\mathrm{N}$ concentrations are to be effective in Ontario, they need to be adjusted for local conditions.

The reasons why the published critical $\mathrm{N}$ concentrations largely did not match the results in this study may be explained by the combination of differences in soil type, cultivars, production practices, and climate. Differences in total $\mathrm{N}$ concentrations between soil types were shown in the rate studies in onions in 2000 and in carrots at the early and midseason sampling stages in both years. At the 5-leaf stage in the onion cultivar study, onions growing in organic soil had nearly $10 \mathrm{~g} \cdot \mathrm{kg}^{-1}$ higher total $\mathrm{N}$ concentrations than onions growing on mineral soil, even though both were supplied with the OMAFRA recommended rate of $\mathrm{N}$ for the respective soil types. These soil type induced differences probably include differences in water availability, levels of other nutrients, $\mathrm{pH}$, and soil microbial activity. However, it is difficult to determine if the differences in all of these studies are entirely related to soil type, or if cultivar differences also played a role.

Cultivar differences were identified in the onion cultivar study where total $\mathrm{N}$ concentration in leaves of 'Hamlet' was $10 \mathrm{~g} \cdot \mathrm{kg}^{-1}$ lower than that in 'Bastille' leaves and the total $\mathrm{N}$ concentration in leaves of 'Candy' was $4 \mathrm{~g} \cdot \mathrm{kg}^{-1}$ higher than that in 'Santos' at the 5-leaf stage. Some reports suggest that $\mathrm{N}$ uptake can be altered by cultivar differences but the critical concentrations often do not change, while many other reports have shown large cultivar differences in many crops (Bates, 1971). Our results support the theory that cultivar differences can cause differences in critical $\mathrm{N}$ concentrations.

HortScience, Vol. 38(6), October 2003 
Table 7. Total nitrogen $(\mathrm{N})$ and $\left(\mathrm{NO}_{3}-\mathrm{N}\right)$ concentrations at 3 sampling stages of carrots grown on organic and mineral soil in Ontario in 2000 and 2001 as affected by rate of $\mathrm{N}$ application.

\begin{tabular}{|c|c|c|c|c|c|c|c|c|}
\hline \multicolumn{2}{|c|}{$\begin{array}{c}\mathrm{N} \text { application rate } \\
\left(\mathrm{kg} \cdot \mathrm{ha}^{-1}\right)\end{array}$} & \multicolumn{3}{|c|}{$\begin{array}{c}\text { Tissue total } \mathrm{N} \text { conc. }{ }^{y} \\
\left(\mathrm{~g}^{\mathrm{k}} \cdot \mathrm{kg}^{-1}\right)\end{array}$} & \multicolumn{3}{|c|}{$\begin{array}{c}\text { Tissue } \mathrm{NO}_{3}-\mathrm{N} \text { conc. }{ }^{y} \\
\left(\mathrm{mg}^{\prime} \cdot \mathrm{kg}^{-1}\right)\end{array}$} & \multirow{2}{*}{$\begin{array}{l}\text { Yield }^{\mathrm{x}} \\
\left(\mathrm{t} \cdot \mathrm{ha}^{-1}\right)\end{array}$} \\
\hline Preplant & Sidedress & Early & Midseason & Late & Early & Midseason & Late & \\
\hline \multicolumn{9}{|c|}{ Organic-2000 } \\
\hline 0 & 0 & 16 & 12 & --- & 3222 & 605 & --- & 25.8 \\
\hline 30 & 0 & 17 & 13 & --- & 3929 & 857 & --- & 22.8 \\
\hline 60 & 0 & 18 & 12 & --- & 4472 & 774 & --- & 22.7 \\
\hline 90 & 0 & 19 & 14 & --- & 5359 & 1158 & --- & 20.2 \\
\hline 120 & 0 & 20 & 14 & --- & 5744 & 1095 & --- & 19.2 \\
\hline \multicolumn{9}{|c|}{ Mineral-2000 } \\
\hline 0 & 0 & 17 & 7 & 7 & 3548 & 317 & 138 & 64.1 \\
\hline 55 & 17.5 & 19 & 8 & 7 & 6373 & 945 & 225 & 79.8 \\
\hline 110 & 35 & 22 & 11 & 8 & 7321 & 2247 & 521 & 73.6 \\
\hline 165 & 52.5 & 25 & 12 & 11 & 11,024 & 3298 & 3038 & 76.7 \\
\hline 220 & 70 & 24 & 12 & 10 & 11,338 & 4421 & 1807 & 74.6 \\
\hline \multicolumn{9}{|c|}{ Organic-2001 } \\
\hline 0 & 0 & 21 & 15 & 11 & 11,015 & 4586 & 1336 & 95.3 \\
\hline 30 & 0 & 21 & 18 & 11 & 10,561 & 5339 & 1621 & 92.8 \\
\hline 60 & 0 & 22 & 14 & 10 & 10,938 & 4769 & 1008 & 89.1 \\
\hline 90 & 0 & 20 & 15 & 11 & 9549 & 4781 & 1574 & 90.1 \\
\hline 120 & 0 & 23 & 15 & 12 & 12,006 & 5209 & 1648 & 87.1 \\
\hline \multicolumn{9}{|c|}{ Mineral-2001 } \\
\hline 0 & 0 & 8 & 8 & 8 & 409 & 115 & 60 & 47.4 \\
\hline 55 & 17.5 & 10 & 8 & 8 & 1217 & 152 & 29 & 49.7 \\
\hline 110 & 35 & 12 & 10 & 10 & 1836 & 491 & 491 & 40.6 \\
\hline 165 & 52.5 & 11 & 11 & 10 & 2158 & 651 & 651 & 48.4 \\
\hline 220 & 70 & 11 & 12 & 11 & 2098 & 1075 & 1075 & 51.6 \\
\hline $\mathrm{CNCs}^{\mathrm{w}}$ & & 18 & $15-18$ & 15 & --- & $7500-10,000$ & --- & \\
\hline
\end{tabular}

${ }^{2}$ Correspond with $0 \%, 50 \%, 100 \%, 150 \%$, and $200 \%$ of the OMAFRA (Ontario Ministry of Agriculture, Food, and Rural Affairs) recommended N application rate.

${ }^{y}$ Regression statistics presented in Table 3; $n=3$ for all but the early sampling stage in $2001(n=4)$.

${ }^{\times}$Regression and analysis of variance are nonsignificant in either soil type.

"Published critical nutrient concentrations from Table 1 applicable to the stage of sampling and plant parts used for the analysis.

The effect of climate on total $\mathrm{N}$ concentrations in the crops was demonstrated in the onion $\mathrm{N}$ source study where there were differences between 5 and $8 \mathrm{~g} \cdot \mathrm{kg}^{-1} \mathrm{~N}$ across all sampling stages between 1999 and 2000. In the rate studies for each crop, there were also differences between 2000 and 2001 results in many instances. It is possible, even with irrigation, that low soil moisture in 1999 and 2001 restricted N uptake. Soil moisture levels can have a significant impact on the result of leaf tissue analysis (Bates, 1971, Fisher, 1980, Farina, 1994). In cabbage, a cool season crop, high air temperatures in 2001 appear to have stunted growth. Grevesen (1998) reported that broccoli growth was stunted at mean temperatures $>17^{\circ} \mathrm{C}$ in Denmark. This did not affect the use of critical total $\mathrm{N}$ concentrations for cabbage, but appears to have had a significant impact on $\mathrm{NO}_{3}{ }_{3}^{-}$concentrations and yield. Clearly, many variables can affect the use of published critical $\mathrm{N}$ concentrations in Ontario, and a better understanding of the effect of these variables would improve the use of critical concentrations for tissue analysis.

The published references are based on research mainly from Florida, California, and Australia. In the case of Florida, cabbage, carrots, and onions are grown typically over the winter months in periods of relatively cool and wet weather compared to the summer conditions in Ontario. The length of the growing season, the photoperiod, the cultivars used, and the soil types on which the crops are grown are very different from those in Ontario. Consequently, since cultivar, soil type, and climate differences within Ontario have an effect on tissue $\mathrm{N}$ concentrations, the large differences between the areas of research and Ontario provide an explanation for the lack of agreement between local data and published critical concentrations.

The main difficulty in using the published critical concentrations was the discrepancies in the stage of sampling. In carrots, the critical nutrient concentrations were most often separated into early, mid, and late growth. In a crop where the growing season can be five to six months long, mid-growth could be anywhere from two to four months after planting, which could explain why the results of the tissue analysis in the carrot experiments did not match the published critical concentrations. Work on a degree-day model to determine when to sample may be warranted. There was also a wide variation that existed in the plant parts that were used both within and among the references. Maynard and Hochmuth (1997), in cabbage, recommended the midrib of a wrapper leaf early in the season and a whole wrapper leaf late in the season, while Mills and Jones (1996) recommended whole tops early in the season, wrapper leaves midseason, and the midrib of a wrapper leaf late in the season (Table 1). This made it impossible to determine which plant part was most appropriate to use at each growth stage. Labs may find that growers often bring in plant parts for which they have no reference to compare the results of the analysis. A greater standardization of sampling procedures would be beneficial in improving the usefulness of tissue analysis for $\mathrm{N}$ management of vegetable crops.

Due to the many factors that affect tissue $\mathrm{N}$ concentrations, it is difficult to establish precise critical concentrations based on two years of data. Furthermore, critical tissue $\mathrm{NO}_{3}-\mathrm{N}$ concentrations cannot be established because of the variability in tissue $\mathrm{NO}_{3}-\mathrm{N}$ concentrations in these studies. However, from this data we suggest the following interim values $\left( \pm 3 \mathrm{~g} \cdot \mathrm{kg}^{-1}\right)$. For cabbage, the critical total $\mathrm{N}$ concentrations are close to 32 , 30 , and $28 \mathrm{~g} \cdot \mathrm{kg}^{-1}$ at the cupping, heading, and mature stages, respectively. The critical total $\mathrm{N}$ concentrations for onions are close to 30,28 , and $25 \mathrm{~g} \cdot \mathrm{kg}^{-1}$ at the 5-leaf, bulbing, and mature stages, respectively. For carrots, the critical total $\mathrm{N}$ concentrations are close to 12,8 , and 6 $\mathrm{g} \cdot \mathrm{kg}^{-1}$ at the early, midseason, and late stages, respectively. A broader database is required to confirm these values and determine more precise critical concentrations.

Total $\mathrm{N}$ analysis of plants could be a useful tool if sampling times and plant parts could be standardized. Climate and cultivar effects could also be factored in. Van Erp and Van Beusichem (1998) suggested that a more scientific approach and a more complex system of tissue testing would be desirable if it is to be used to its full advantage. Hochmuth (1995) recognized the need to standardize sampling procedures because labs often have difficulty providing diagnoses and recommendations due to incorrect sample collection. In addition, advisors, farmers, and researchers often reduce sample integrity by taking shortcuts in time, effort, and cost (Farina, 1994). Improving the procedures and standards for tissue sampling will clearly require a concerted effort from all sectors of the system.

If growers and crop advisors are to depend on the published critical $\mathrm{N}$ concentrations to enhance the $\mathrm{N}$ efficiency of their production systems, local research is required. Using the published critical $\mathrm{N}$ concentrations and adjusting them to correspond with local conditions would require considerable research, but could make tissue analysis useful in managing fertilization practices. Possible modifications to the current system such as factoring in growth rates to provide a single critical nutrient concentration for an entire growing season (Scaife, 1988) and using nutrient ratios to eliminate compounding nutrient problems (Sumner, 1990), should be investigated. Furthermore, this research shows that critical $\mathrm{N}$ concentrations and tissue analysis in general probably should not be the sole crop diagnostic tool that is used because of the errors that are possible. Soil analysis and alternative tools such as in-field chlorophyll and nitrate meters should be investigated further as supplements to the production system.

\section{Literature Cited}

Archibald,J.A. 1964. Weather effects on leaf-nutrient composition of fruit crops, p. 1-8. In: C. Bould, 
P. Prevot, and J.R. Magness (eds.). Plant analysis and fertilizer problems IV. ASHS, Humphrey Press, Geneva, N.Y.

Barker, A.V., N.H. Peck, and G.E. MacDonald. 1971. $\mathrm{NO}_{3}-\mathrm{N}$ accumulation in vegetables. I. Spinach grown in upland soil. Agron. J. 63: 126-129.

Bates, T.E. 1971. Factors affecting critical nutrient concentrations in plants and their evaluation: A review. Soil Science 112(2):116-130.

Caldwell, J.O'N, M.E. Sumner, and C.S. Vavrina. 1994. Development of preliminary foliar DRIS norms for onions. HortScience 29(12): 1501-1504.

Dangler, J.M. and C.W. Wood. 1993. Nitrogen rate, cultivar, and within-row spacing affect collard yield and leaf nutrient concentration. HortScience 28(7):701-703.

Dow, A.I. and S. Roberts. 1982. Proposal: Critical nutrient ranges for crop diagnosis. Agron. J. 74:401-403.

Farina, M.P.W. 1994. Improving the quality of soil and plant samples. Commun. Soil Sci. Plant Analysis 25(7\&8):781-797.

Fisher, M.J. 1980. The influence of water stress on nitrogen and phosphorus uptake and concentrations in Townsville stylo (Stylosanthes humilis). Austral. J. Expt. Agr. Anim. Husb. 20:175-180.

Freyman, S., P.M. Toivonen, P.W. Perrin, W.C. Lin, and J.W. Hall. 1991. Effect of nitrogen fertilization on yield, storage losses and chemical composition of winter cabbage. Can. J. Plant Sci. 71:943-946.

Greenwood, D.J., A. Barnes, K. Liu, J. Hunt, T.J. Cleaver, and S.M.H. Loquens. 1980. Relationships between the critical concentrations of nitrogen, phosphorus and potassium in 17 different vegetable crops and duration of growth. J. Sci. Food Agr. 31:1343-1353.
Grevesen, K., 1998. Effects of average temperature on head growth of broccoli (Brassica oleracea Var italica); Parameter estimates for a predictive model. J. of Hort. Sci. and Biotech. 73: 235-244.

Hochmuth, G. 1995. Sampling techniques key in tissue analysis. Amer. Veg. Grower, Nov.:30-31.

Huett, D.O. and G. Rose. 1989. Diagnostic nitrogen concentrations for cabbages grown in sand culture. Austral. J. of Expt. Agr. 29:883-892.

Lorenz, O.A. and K.B. Tyler. 1976. Plant tissue analysis of vegetable crops, p. 21-24. In: Soil and plant tissue testing in California. Univ. Calif. Div. Agr. Sci. Bul. 1879.

Macy, P. 1936. The quantitative mineral nutrient requirements of plants. Plant Physiol. 11: 749-764.

Maier, N.A., A.P. Dahlenburg, and T.K. Twigden. 1990. Assessment of the nitrogen status of onions (Allium cepa L.) cv. Cream Gold by plant analysis. Austral. J. Expt. Agr. 30:853-859.

Maynard, D.N. and A.V. Barker. 1974. Nitrate accumulation in spinach as influenced by leaf type. J. Amer. Soc. Hort. Sci. 99(2):135-138.

Maynard, D.N. and G.J. Hochmuth. 1997. Knott's handbook for vegetable growers. 4th ed. Wiley, Toronto.

Mills, H.A. and J.B. Jones, Jr. 1996. Plant analysis handbook II. MicroMacro Publishing. Athens, Ga.

Munson, R.D. and W.L. Nelson. 1973. Principles and practices in plant analysis, p. 223-247. In: L.M. Walsh, and J.D. Beaton (eds.). Soil testing and plant analysis, revised edition. Soil Sci. Soc. Amer., Madison, Wis.

Ontario Ministry of Agriculture, Food, and Rural Affairs. 2000. Vegetable production recommendations. Publ. 363. Queen's Printer for Ontario, Toronto.

Piggott, T.J. 1986. Vegetable crops. p. 148-187.
In: Reuter, D.J. and J.B. Robinson (eds.). Plant analysis: An interpretation manual. Inkata Press, Sydney, Australia.

Scaife, A. 1988. Derivation of critical concentrations for growth rate from data from field experiments. Plant and Soil. 109:159-169.

Sorensen, J.N. 2000. Ontogenetic changes in macro nutrient composition of leaf-vegetable crops in relation to plant nitrogen status: A review. J. Veg. Crop. Prod. 6(1):75-96.

Steyn, W.J.A. 1961. The errors involved in the sampling of citrus and pineapple plants for leaf analysis purposes. p. 409-430. In: W. Reuther, (ed.) Plant analysis and fertilizer problems. Amer. Inst.of Biol. Sci., Washington, D.C.

Sumner, M.E. 1990. Advances in the use and application of plant analysis. Commun. Soil Sci. Plant Analysis 21(13-16):1409-1430.

Ulrich, A. 1952. Physiological bases for assessing the nutritional requirements of plants. Ann. Rev. Plant Physiol. 3:207-228.

Van Erp, P.J. and M.L. Van Beusichem. 1998. Soil and plant testing programs as a tool for optimizing fertilizer strategies. J. of Crop Prod. 1(2): 53-80.

Warman, P.R. and K.A. Havard. 1997. Yield, vitamin and mineral contents of organically and conventionally grown carrots and cabbage. Agr., Ecosystems \& Environ. 61:155-162.

Warncke, D.D. 1996. Soil and plant tissue testing for nitrogen management in carrots. Commun. Soil Sci. Plant Analysis. 27(3\&4):597-605.

Zebarth, B.J., S. Freyman, and C.G. Kowalenko. 1991. Influence of nitrogen fertilization on cabbage yield, head nitrogen content and extractable soil inorganic nitrogen at harvest. Can. J. Plant Sci. 71:1275-1280.

Zink, F.W. 1966. Studies on the growth rate and nutrient absorption of onion. Hilgardia 37(8): 203-211. 